\title{
Simulation Tests of Determining Under Keel Clearance for LNG Carrier at Anchorage
}

\author{
P. Mrozowski, H. Śniegocki \& P. Wilczyński \\ Gdynia Maritime University, Gdynia, Poland
}

\begin{abstract}
The article presents issues related to the determination of under keel clearance for LNG carrier at anchorage. The processes related to the acquisition and analysis of data affecting the safety of anchoring operations have been presented. The collected data made it possible to achieve the research goal, which was to assess the variability of under keel clearance in simulated scenarios for various hydro-meteorological conditions observed in the area of the anchorage. The result of the simulation tests is to identify the risks that may occur during anchoring of the LNG carrier and the presented issues may be helpful in safe planning of the anchorage for LNG ships.
\end{abstract}

\section{INTRODUCTION}

Technological development causes a significant demand for energy. The data from recent decades have indicated an increased demand for energy fuels. The costs of transporting liquid fuels resulted in changes in the means of transport, namely LNG tankers. A significant change is primarily the increase in the dimensions of the vessels. The increase in linear parameters of LNG tankers, and above all their draft, means that a significant problem to be solved is the safe under keel clearance, both during navigation and at anchorage. The need to analyze and determine the safe under keel clearance, for a given area at different times of the year is very important. When approaching a port, a ship is often stopped at an anchorage to wait for her berth or to wait out bad weather conditions. Each port has an area designated by the Maritime Administration of the Coastal State meant for anchoring ships. The simulation studies presented the problem of determining under keel clearance for tankers in areas with restricted depth. The Baltic Sea itself and approaches to many ports are areas of relatively shallow depth, while tankers have a deep draft and it means the necessity to accurately determine safe under keel clearance both during the approach and at the anchorage.

\section{REVIEW OF THE SUBJECT LITERATURE}

The construction and commissioning of the LNG Terminal in Świnoujście, as well as regular calls of Qmax LNG carriers evoke the need to acquire knowledge and to assess the possibility of anchoring of this type of vessels in the area of the Pomeranian Bay.

Literature available in Poland on the calls of LNG carriers at the port of Świnoujście mainly covers issues related to safe passage through the Baltic Sea, approach to the port and risk assessment for the transport of this type of cargo which is presented below. 
These are studies prepared, among others, by the team of the Institute of Marine Traffic Engineering and the Maritime University of Szczecin, e.g. „Analiza nawigacyjna budowy stanowiska rozładunkowego LNG w porcie zewnętrznym w Świnoujściu",,,Ilościowa analiza ryzyka morskiej części lokalizacji Terminalu LNG w Świnoujściu", "Minimalne wymagane parametry podejściowych torów wodnych do Portu Świnoujście" S. Gucma, „Inżynieria Morska i Geotechnika”, nr 2/2011 r. autorstwa S. Gucma, „Ilościowa analiza ryzyka morskiej części lokalizacji terminalu LNG w Świnoujściu”, Szczecin 2010 r. (S. Gucma), Rutkowski G., "Modelowanie domeny statku w procesie manewrowania w ograniczonych akwenach", Politechnika Warszawska Wydział Transportu, Prace Naukowe Warsaw University of Technology, Faculty of Transport, Research "T", Warszawa 2001 r., Rutkowski G., „Ocena głębokości północnego toru podejściowego do portu Świnoujście od pozycji gazociągu NordStream do terminal LNG w aspekcie obsługi jednostek o maksymalnych gabarytachmetody uproszczone" Faculty of navigation, Gdynia Maritime University. Rutkowski G., "Zastosowanie modelu domeny do oceny bezpieczeństwa nawigacyjnego statków poruszających się $w$ akwenach ograniczonych", Politechnika Warszawska Wydział Transportu, Prace Naukowe „T", Warszawa 2001 r. Warsaw University of Technology, Faculty of Transport, Scientific Works "T", Warsaw 2001 Rutkowski G., Królikowski A., „Ocena głębokości toru podejściowego na południe od Ławicy Słupskiej w aspekcie obsługi jednostek o maksymalnych gabarytach - metoda rozbudowana". Publikacja w Zeszytach Naukowych AMW Publication in AMW Scientific Journals, ISSN 0860-889X, Zeszyt Nr 1 (180), Str.81-96, Gdynia 2010 r.

The following publications, inter alia, can be listed in foreign literature, the content of which was taken into account during the simulation process:

A Guide and in Port Approaches, 3rd Ed, ICS, 1999 r., A Guide to Contingency Planning for the Gas Carrier Alongside and Within Port Limits, 2nd Ed, ICS, 1999 r., A Guide to good practice on port Marine Operation- prepared in conjunction with the Port Marine Safety Code, 2009 r., Admiralty List of Radio Signals, Volume 6(2), NP286 (2), edycja 2009/2010 r., Admiralty Sailing Directions, Baltic Pilot, Volume I, NP18, edycja 15/2010 r., Aids to Navigation Manual Administration, Comdtinst M16500.7A, 2 Mar 2005 r., Bridge Procedures Guide, 1998, ICS, Coastal Engineering Manual - Part 5, August 2008, publ. nr EM1110-2-1100, Code for existing ships carrying Liquefied Gases in Bulk- IMO, Code for the construction and equipment of ship carrying liquefied gases in bulk, 1983 Edition Code for the construction and equipment of ship carrying liquefied gases in bulk, IGC ; Code 1993 Edition, COLREG, 1977 with amendments IMO, Critical Incident Management Guidelines, Volpe National Transportation Systems Center, 17 April 1998 r., Critical parameters for LNG Marine Terminal Site Selection (OTC 19658 Offshore Technology Conference, Houston 2008 r.)

The analysis of literature shows that few scientists and authors of articles have become interested in the problem of UKC of LNG ships at anchor in shallow waters. The proposed scope of simulation studies covers exactly this area of knowledge where little has been presented so far to deal with the problem of UKC of a vessel at anchor.

\section{SIMULATION RESEARCH}

The area of the Pomeranian Bay, No.3 anchorage was selected for the simulation tests. All tests were carried out at the Faculty of Navigation of the Gdynia Maritime University using the NaviTrainer 5000 Professional navigation and maneuvering simulator, ECDIS Navi-Sailor 4000 systems, the electronic chart simulator and Model Wizard application (v. 5.0). The ship model used for the research was LNG carrier (Figure 1), loaded condition with the following: parameters $\mathrm{L}=315 \mathrm{~m}, \mathrm{~B}=50 \mathrm{~m}, \mathrm{~T}=12 \mathrm{~m}$, without trim. Ship model particulars are presented in Fig. 2 and Fig. 3.

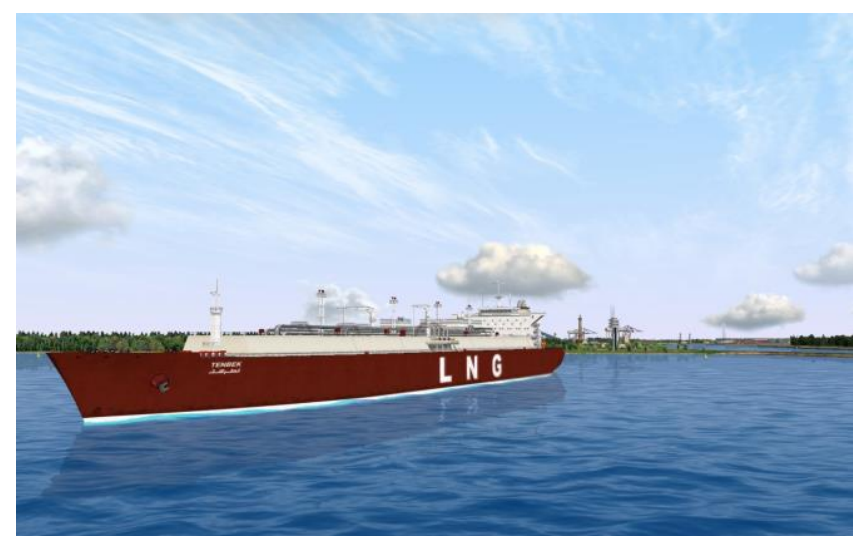

Figure 1 Model of LNG carrier used for simulation

Due to lack of precise and up-to-date data on waves and sea currents occurring in the area covered by simulation, wave parameters have been calculated. It should be pointed out that the results of wave tests available in literature in the considered water area are characterized by significant differences in the obtained values of height and direction of wind wave as a function of wind speed vector.

In the initial simulation tests a comparative analysis of wave spectrum was carried out for two models, i.e. ITTC and JONSWAP respectively. The JONSWAP model was adopted for wind wave spectrum. The wave height adopted in the settings of initial parameters should be understood as the height of significant wave expressed in meters. Significant wave height distribution was generally prepared for eight wind directions (N, NE, E, SE, S, SW, W, NW).

In simulation tests the value of $6 \mathrm{~m} / \mathrm{s}$ was adopted as the greatest lower bound of wind speed.

The average parameters of the generated waves were determined for winds (without squalls) of speed of $6,9,12,15$ and $15.1-18.0 \mathrm{~m} / \mathrm{s}$ every $0.1 \mathrm{~m} / \mathrm{s}$ and for $6,9,12,12.2-15.0 \mathrm{~m} / \mathrm{s}$ every $0.2 \mathrm{~m} / \mathrm{s}$ and 15.118.0 every $0.1 \mathrm{~m} / \mathrm{s}$.

Kryłów and Titov method was taken into account while determining the wave parameters for 
simulation purposes, in particular the height of the wind wave in relation to the wind speed,

The latter, taking into account its purely theoretical assumptions, computationally generates values of significant wave height obtained in the JONSWAP model for maximum values of wind wave parameters and for the value of fetch limited case of wind speed necessary for their formation.

In the coastal zone waves are transformed due to shallower bathymetry. The calculated wavelength parameters were transformed, by means of the above methods, assuming an estimated set of wave height values for a given wind speed in advance, due to the occurring phenomenon of refraction associated with the curvature of the wave crest lines and consequently the change in phase velocity, and thus the wavelength,

The model was adopted for regular undulations of a given direction of wave propagation, of certain height and period of the wave. The results of calculations of wave parameters were compared to the obtained results of research and observations in the southern part of the Pomeranian Bay, taking into account refraction and additionally compared to the analysis of observations of the wave field in the Baltic Sea used in the expansion and modernization of the ports in Gdańsk and Władysławowo. The local bathymetry system affects changes in the direction of wave radii.

Statistical analysis of data on behavior of LNG carrier model at anchor was carried out on the basis of simulations performed and discussed below and the StatGraphics program.
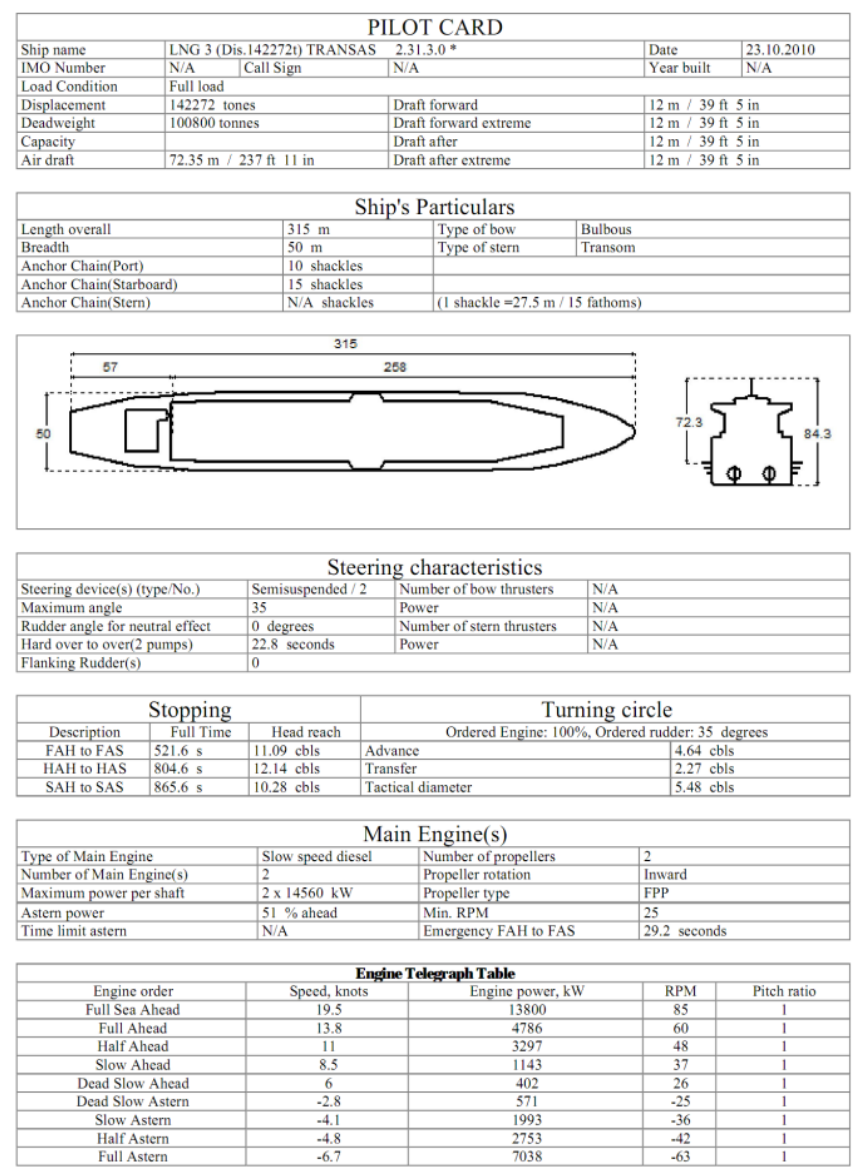

Figure 2. Pilot Card

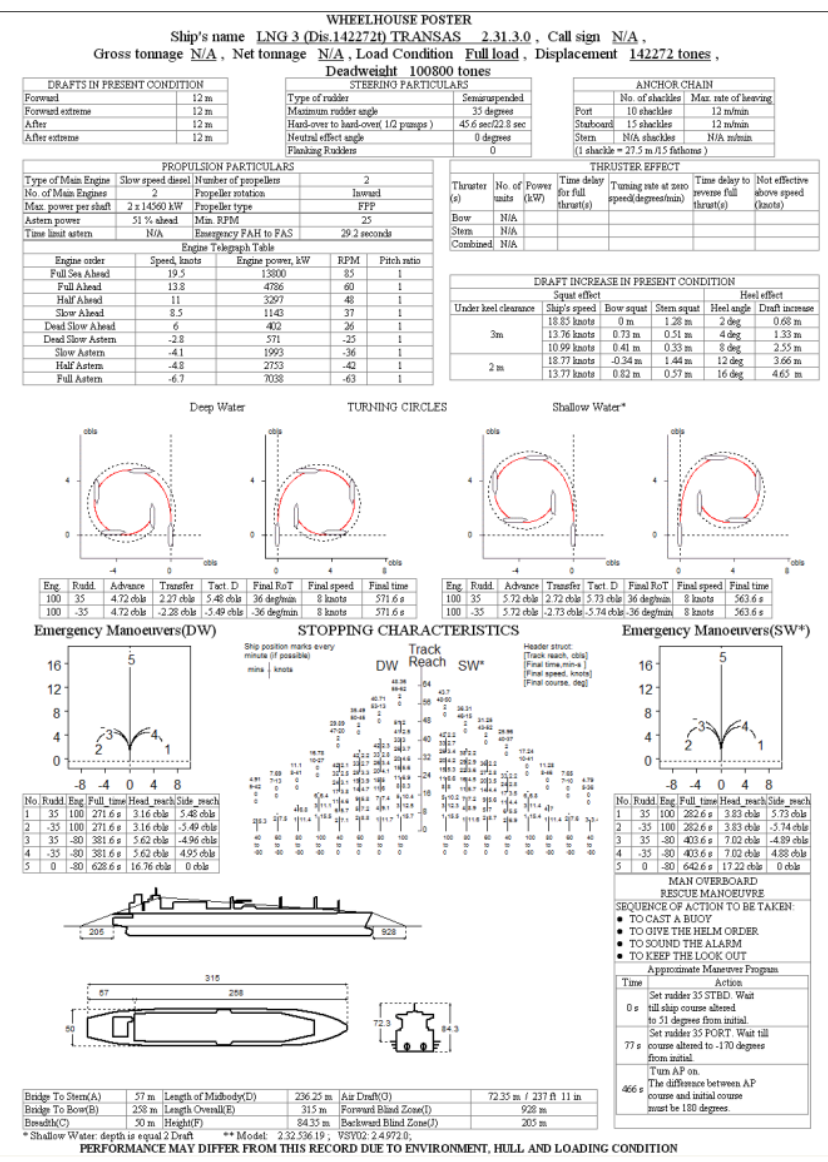

Figure 3. Wheelhouse poster

\section{SIMULATION TESTS- NO. 3 ANCHORAGE, EXTERNAL PORT IN ŚWINOUJŚCIE.}

Parameters of No.3 anchorage of the external port in Świnoujście were used in simulation scenario of the behaviour of a model of LNG carrier at anchor.

In the simulation series, a $15.5 \mathrm{~m}$ lowest depth was assumed in the entire area of the anchorage. The ship lies at anchor, port anchor with the length of the anchor cable of 7 shackles. The simulation begins after the initial positioning of the model at anchor in relation to the operating disturbances (wind, undulations). A continuous time tape with a nominal length of 03:00:00 [hh: $\mathrm{mm}$ : ss] was built, in which for the given wave spectrum the wind speed and the wave height are continuous non-decreasing functions. In the simulation, the wind speed domain was limited to the value of $6 \mathrm{~m} / \mathrm{s}$. The parameters of the generated waves were determined and the results of simulation tests were obtained for winds (without squalls) of the speed of $6,9,12,1 \mathrm{~m} / \mathrm{s}$ and $15.1-18.0$ $\mathrm{m} / \mathrm{s}$ every $0.1 \mathrm{~m} / \mathrm{s}$. The moment of complete loss of under keel clearance (hull contact with the bottom) was assumed as the end of the simulation. An example of a screenshot from electronic navigation chart with positions (contour) of LNG ship model at anchor is shown in Fig. 4. 


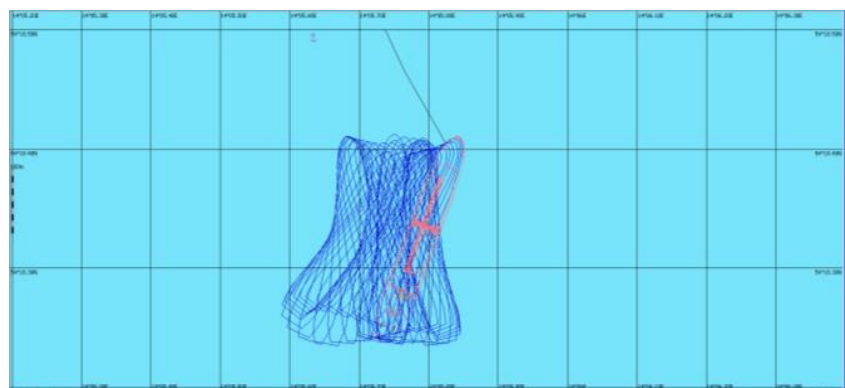

Figure 4. An example of a screenshot from electronic navigation chart with the positions (contour) of LNG ship model at anchor.

The simulation, in particular, examined the course of the variability of under keel clearance (UKC) with the set disturbance parameters (hydro-meteorological conditions). The wind speed/velocity ( $\mathrm{vw}$ ) and the change of under keel clearance in the bow and stern parts obtained from measurements based on sensors located in the symmetry line of the bottom of the LNG carrier model are presented in the attached graphs below as a function of time.

In connection with the implementation of the task consisting in determining the boundary conditions, the attached drawings (Fig. 5-Fig. 13) present the results of tests, covering the period of the last 5 minutes of the simulation. The positive value of under-keel clearance, read each time, at the end of the simulation, is related to the hull contact with the bottom at the occurrence of the ship's rolling. Simulations were also carried out, taking into account additional influence of squalls (No.134, 134a, 136 simulations) and swell (No.129-133 and 136 simulations). The parameters of the simulations have been presented in Tab. 1.

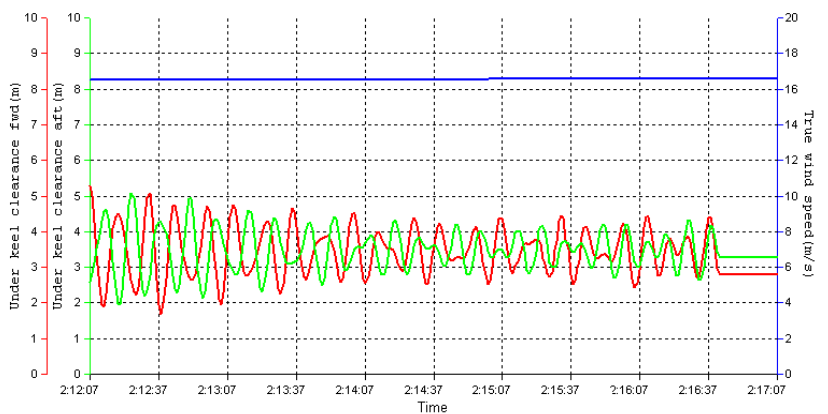

Under keel clearance $f w d(m)$

ue wind $s p e e d(\mathrm{~m} / \mathrm{s})$

Figure 5 .Graph of UKC changes and $\mathrm{V}_{\mathrm{w}}$ (No. 109 simulation)

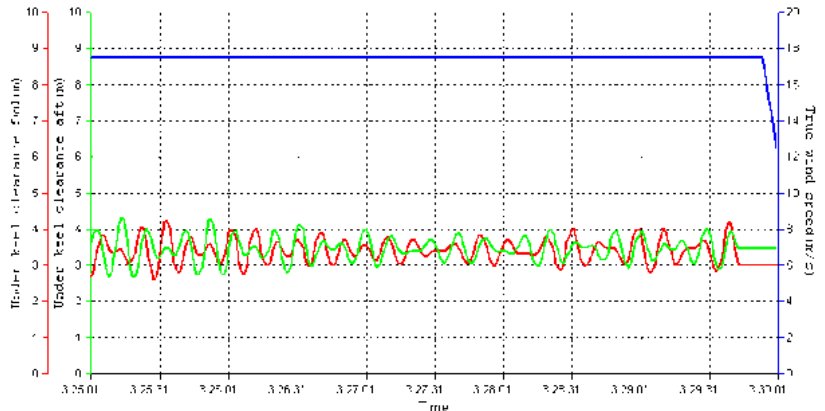

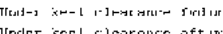

Under $k \mathrm{sel}$ clearance

Figure 6. Graph of UKC changes and $\mathrm{V}_{\mathrm{w}}$ (No. 134a simulation)

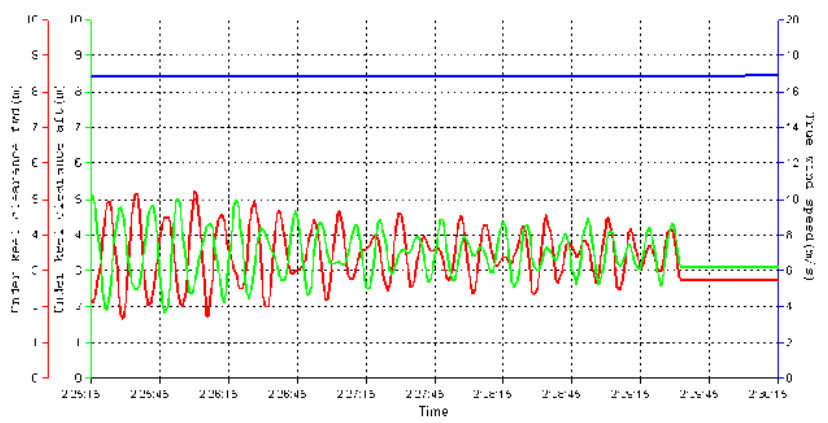

inder keel cleacanze fud im

niter keel cleasan:e

Figure 7. Graph of UKC changes and $\mathrm{V}_{\mathrm{w}}$ (No. 129 simulation)

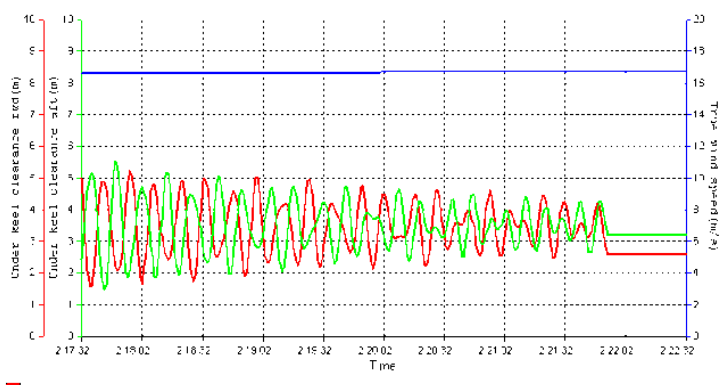

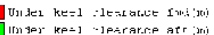

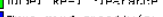

Figure 8. Graph of UKC changes and $\mathrm{V}_{\mathrm{w}}$ (No. 130 simulation)

Table 1. Simulation parameters of the model of LNG carrier at anchor.

\begin{tabular}{lllllll}
\hline $\begin{array}{l}\text { No. of } \\
\text { simulations }\end{array}$ & $\begin{array}{l}\text { True wind } \\
\text { direction } \\
{\left[{ }^{\circ}\right]}\end{array}$ & $\begin{array}{l}\text { Wind } \\
\text { Direction } \\
\left.{ }^{\circ}\right]\end{array}$ & $\begin{array}{l}\text { Swell } \\
\text { Hdg } \\
{\left[{ }^{\circ}\right]}\end{array}$ & Squalls & $\begin{array}{l}\text { Dragging } \\
\text { anchor }\end{array}$ & $\begin{array}{l}\text { Contact with the bottom } \\
\text { Wind speed/velocity } \\
\text { Vw [m/s] }\end{array}$ \\
\hline 109 & 000 & 000 & - & No & No & 16,6 \\
134 & 000 & 000 & - & Yes & Yes & - \\
$134 a$ & 000 & 000 & - & Yes & No & 17,5 \\
136 & 000 & 000 & 045 & Yes & No & 17,1 \\
129 & 000 & 000 & 000 & No & No & 16,8 \\
130 & 000 & 000 & 045 & No & No & 16,7 \\
131 & 000 & 000 & 090 & No & No & 16,9 \\
132 & 000 & 000 & 135 & No & No & 17,3 \\
133 & 000 & 000 & 180 & No & No & 16,6 \\
\hline
\end{tabular}




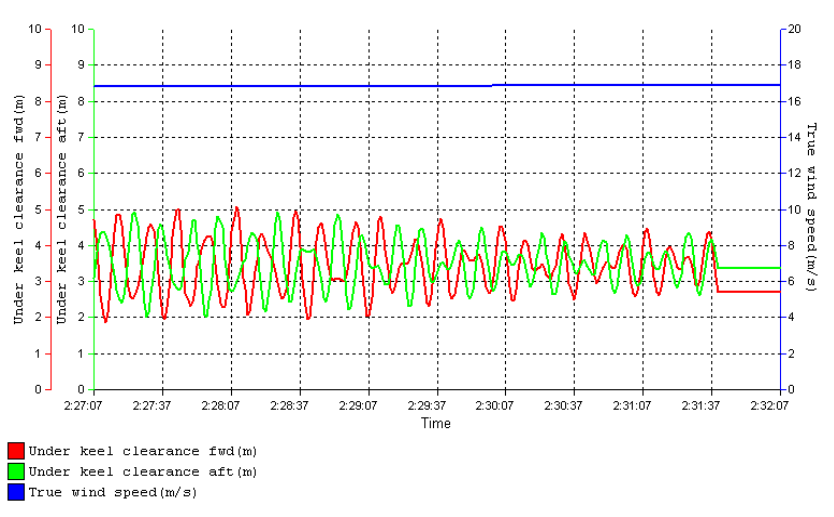

Figure 9. Graph of UKC changes and $V_{w}$ (No. 131 simulation)

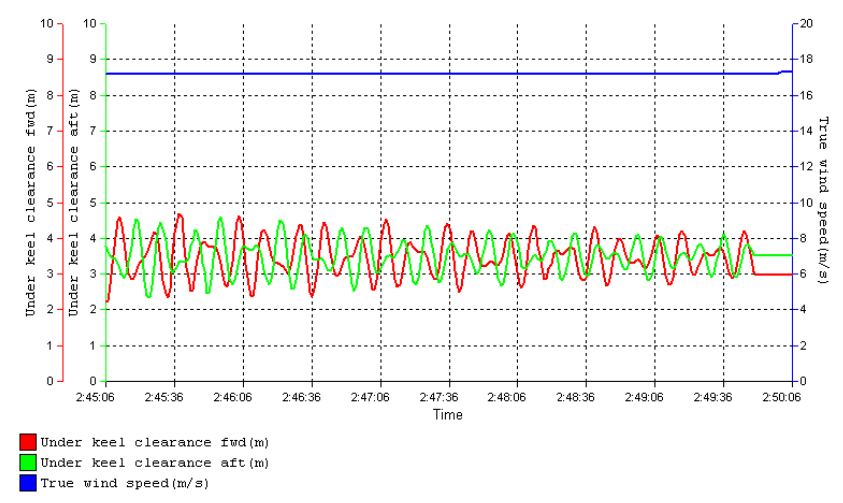

Figure 10. Graph of UKC changes and $\mathrm{V}_{\mathrm{w}}$ (No. 132 simulation)

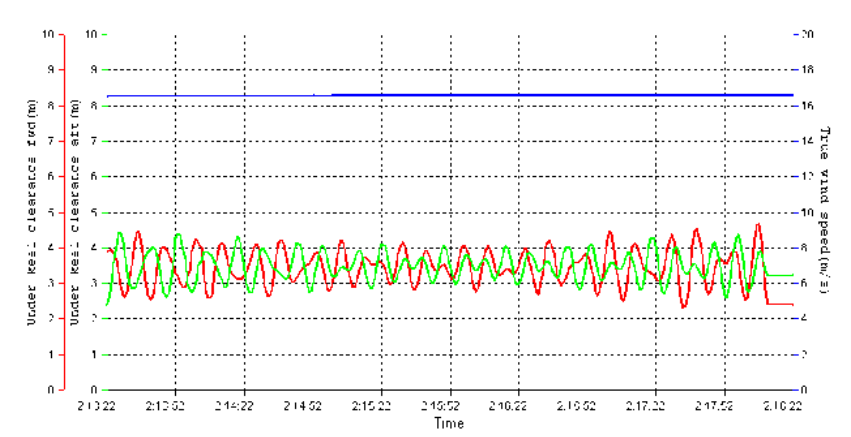

Duscer zeel zlearance rval ino

Woder keel -learance aft im

Figure 11. Graph of UKC changes and $V_{w}$ (No. 133 simulation)

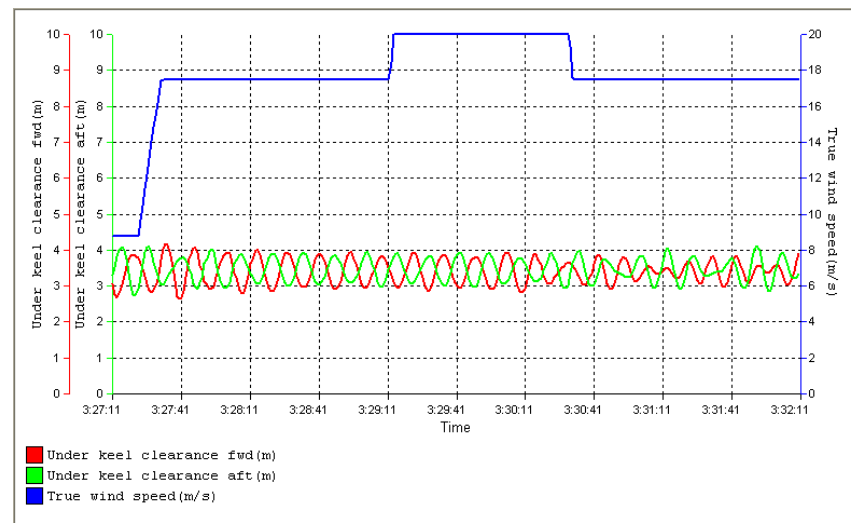

Figure 12. Graph of UKC changes and $V_{w}$ (No. 134 simulation)

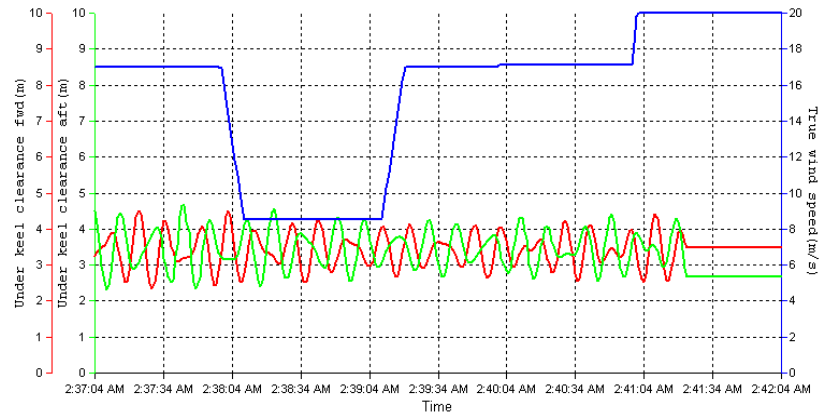

$\square$ Under keel clearance fud (m)

Under keel clearance

Figure 13 Graph of UKC changes and Vw (No. 136 simulation)

The developed theoretical model examines the under keel clearance of LNG ship at anchor and the boundary conditions of the ship's contact with the bottom. Based on the carried out simulation studies and the need for high accuracy and precision of the measurements of the UKC for LNG carrier, new measurements of hydro-meteorological conditions must be carried out in order to collect current and accurate data, in particular the observed wave and current parameters in the Pomeranian Bay area, with particular emphasis on the expected trajectory of LNG carriers calling at the port of Świnoujście (including the approach channel and anchorages). The observations of the maritime administration services responsible for the measurements in the Pomeranian Bay area indicate that the pressure change itself associated with the transition of the barometric systems induces a significant change in the water level in the approach channel, which is expressed in the differences in the depth reading. The knowledge of at least an estimate of frequent changes in depth caused by a change in specific hydrometeorological conditions is of significant importance in determining the expected under keel clearance for master of LNG vessel that is fully loaded and the shore side services (Captain's Office, VTS, pilot station) co-responsible for safe passage of the ship to the LNG terminal in Swinoujście. Changes in the water level significantly affect the actual depth. The accuracy of the depth determination by hydrographic institutions is strictly defined by relevant IMO regulations, in particular, of a water depth of 10.0$20.0 \mathrm{~m}$, the measurement accuracy is $0.20 \mathrm{~m}$.

The greatest hazard in shallow water, which has been the cause of many contacts of a hull with seabed, is the undulations and related movements of a ship, which obviously reduce the distance between the hull and the bottom. Table 2 shows examples of reduction in under keel clearance for tankers of various dimensions caused by undulations/ wind wave. 
Table 2. Reduction in UKC caused by the waves[1]

\begin{tabular}{|c|c|c|c|c|c|c|c|c|c|c|c|c|c|c|}
\hline $\begin{array}{l}\text { Ship's } \\
\text { particulars }\end{array}$ & $\begin{array}{l}\text { Wave } \\
\text { Hight } \\
{[\mathrm{m}]}\end{array}$ & Period & $\begin{array}{l}\text { WAVE D } \\
000^{\circ} \\
\text { Pitching } \\
{[\mathrm{m}]}\end{array}$ & $\begin{array}{l}\text { DIRECTI } \\
\text { Heave } \\
{[\mathrm{m}]}\end{array}$ & $\begin{array}{l}\text { Sum } \\
{[\mathrm{m}]}\end{array}$ & $\begin{array}{l}090^{\circ} \\
\text { Rolling } \\
{[\mathrm{m}]}\end{array}$ & $\begin{array}{l}\text { Heave } \\
{[\mathrm{m}]}\end{array}$ & $\begin{array}{l}\text { Sum } \\
{[\mathrm{m}]}\end{array}$ & $\begin{array}{l}045^{\circ} \text { or } 1 \\
\text { Pitching } \\
{[\mathrm{m}]}\end{array}$ & $\begin{array}{l}35^{\circ} \\
\text { Rolling } \\
{[\mathrm{m}]}\end{array}$ & $\begin{array}{l}\text { Heave } \\
{[\mathrm{m}]}\end{array}$ & $\begin{array}{l}\text { Sum Fwd } \\
\text { or Aft [m] }\end{array}$ & $\begin{array}{l}\text { Midship } \\
{[\mathrm{m}]}\end{array}$ & $\begin{array}{l}\text { Fwd or } \\
\text { Aft }[\mathrm{m}]\end{array}$ \\
\hline $\begin{array}{l}\text { Deadweight } \\
=17049 \mathrm{t} \\
\mathrm{L}=149,00 \mathrm{~m} \\
\mathrm{~B}=21,60 \mathrm{~m} \\
\mathrm{~T}=9,14 \mathrm{~m}\end{array}$ & $\begin{array}{r}4,57 \\
1,83\end{array}$ & $\begin{array}{l}10 \\
10\end{array}$ & $\begin{array}{l}2,80 \\
1,07\end{array}$ & $\begin{array}{l}0,15 \\
0,06\end{array}$ & $\begin{array}{l}2,96 \\
1,13\end{array}$ & $\begin{array}{l}2,93 \\
1,13\end{array}$ & $\begin{array}{l}2,13 \\
0,91\end{array}$ & $\begin{array}{l}5,06 \\
2,04\end{array}$ & $\begin{array}{l}2,50 \\
0,97\end{array}$ & $\begin{array}{l}2,35 \\
0,91\end{array}$ & $\begin{array}{l}0,76 \\
0,30\end{array}$ & $\begin{array}{l}3,26 \\
1,28\end{array}$ & $\begin{array}{l}3,11 \\
1,22\end{array}$ & $\begin{array}{l}3,93 \\
1,52\end{array}$ \\
\hline $\begin{array}{l}\text { Deadweight } \\
=37594 \mathrm{t} \\
\mathrm{L}=203,00 \mathrm{~m} \\
\mathrm{~B}=28,00 \mathrm{~m} \\
\mathrm{~T}=10,97 \mathrm{~m}\end{array}$ & $\begin{array}{r}4,57 \\
1,83\end{array}$ & $\begin{array}{l}10 \\
10\end{array}$ & $\begin{array}{l}2,80 \\
1,07\end{array}$ & $\begin{array}{l}0,30 \\
0,12\end{array}$ & $\begin{array}{l}3,11 \\
1,14\end{array}$ & $\begin{array}{l}3,78 \\
1,46\end{array}$ & $\begin{array}{l}1,52 \\
0,61\end{array}$ & $\begin{array}{l}5,30 \\
2,07\end{array}$ & $\begin{array}{l}2,50 \\
0,97\end{array}$ & $\begin{array}{l}3,05 \\
1,16\end{array}$ & $\begin{array}{l}0,53 \\
0,21\end{array}$ & $\begin{array}{l}3,05 \\
1,19\end{array}$ & $\begin{array}{l}3,58 \\
1,37\end{array}$ & $\begin{array}{l}4,42 \\
1,68\end{array}$ \\
\hline $\begin{array}{l}\text { Deadweight } \\
=45722 \mathrm{t} \\
\mathrm{L}=216,00 \mathrm{~m} \\
\mathrm{~B}=29,80 \mathrm{~m} \\
\mathrm{~T}=11,58 \mathrm{~m}\end{array}$ & $\begin{array}{r}4,57 \\
1,83\end{array}$ & $\begin{array}{l}10 \\
10\end{array}$ & $\begin{array}{l}2,74 \\
0,91\end{array}$ & $\begin{array}{l}0,24 \\
0,09\end{array}$ & $\begin{array}{l}2,99 \\
1,00\end{array}$ & $\begin{array}{l}4,02 \\
1,55\end{array}$ & $\begin{array}{l}1,07 \\
0,49\end{array}$ & $\begin{array}{l}5,09 \\
2,04\end{array}$ & $\begin{array}{l}2,47 \\
0,82\end{array}$ & $\begin{array}{l}3,20 \\
1,25\end{array}$ & $\begin{array}{l}0,37 \\
0,15\end{array}$ & $\begin{array}{l}2,83 \\
0,97\end{array}$ & $\begin{array}{l}3,57 \\
1,40\end{array}$ & $\begin{array}{l}4,39 \\
1,68\end{array}$ \\
\hline $\begin{array}{l}\text { Deadweight } \\
=60963 \mathrm{t} \\
\mathrm{L}=236,00 \mathrm{~m} \\
\mathrm{~B}=32,90 \mathrm{~m} \\
\mathrm{~T}=12,44 \mathrm{~m}\end{array}$ & $\begin{array}{r}4,57 \\
1,83\end{array}$ & $\begin{array}{l}10 \\
10\end{array}$ & $\begin{array}{l}2,47 \\
0,82\end{array}$ & $\begin{array}{l}0,15 \\
0,08\end{array}$ & $\begin{array}{l}2,62 \\
0,91\end{array}$ & $\begin{array}{l}4,45 \\
1,74\end{array}$ & $\begin{array}{l}0,82 \\
0,33\end{array}$ & $\begin{array}{l}5,27 \\
2,07\end{array}$ & $\begin{array}{l}2,22 \\
0,73\end{array}$ & $\begin{array}{l}3,57 \\
1,37\end{array}$ & $\begin{array}{l}0,29 \\
0,11\end{array}$ & $\begin{array}{l}2,53 \\
0,85\end{array}$ & $\begin{array}{l}3,87 \\
1,49\end{array}$ & $\begin{array}{l}4,60 \\
1,74\end{array}$ \\
\hline $\begin{array}{l}\text { Deadweight } \\
=81284 \mathrm{t} \\
\mathrm{L}=257,00 \mathrm{~m} \\
\mathrm{~B}=36,30 \mathrm{~m} \\
\mathrm{~T}=14,02 \mathrm{~m}\end{array}$ & $\begin{array}{r}4,57 \\
1,83\end{array}$ & $\begin{array}{l}10 \\
10\end{array}$ & $\begin{array}{l}2,20 \\
0,97\end{array}$ & $\begin{array}{l}0,12 \\
0,00\end{array}$ & $\begin{array}{l}2,38 \\
0,97\end{array}$ & $\begin{array}{l}4,88 \\
1,89\end{array}$ & $\begin{array}{l}0,61 \\
0,24\end{array}$ & $\begin{array}{l}5,49 \\
2,13\end{array}$ & $\begin{array}{l}1,98 \\
0,88\end{array}$ & $\begin{array}{l}3,90 \\
1,52\end{array}$ & $\begin{array}{l}0,21 \\
0,08\end{array}$ & $\begin{array}{l}2,19 \\
0,97\end{array}$ & $\begin{array}{l}4,11 \\
1,61\end{array}$ & $\begin{array}{l}4,75 \\
1,92\end{array}$ \\
\hline
\end{tabular}

Calculation of UKC at anchorage on the basis of simulation tests was determined on the basis of the following formulas:

$$
\begin{aligned}
& \text { UKC }(\text { symulator })= \\
& \min (\text { Under Keel Clearance fwd }(m), \text { Under Keel Clearance aft }(m))
\end{aligned}
$$$$
U K C=U K C(\text { symulator })-25 \cdot\left|\sin \left(\frac{\operatorname{Roll} \operatorname{angle}\left({ }^{\circ}\right) \cdot \pi}{180^{\circ}}\right)\right| .
$$

where:

under keel clearance fwd(m)- UKC on the FWD [m], under keel clearance aft(m) - UKC at AFT [m], roll angle - rolling.

\section{STATISTICAL ANALYSIS OF SIMULATION RESULTS FOR A MODEL OF LNG CARRIER AT ANCHOR.}

The basic statistical parameters of the data obtained from simulations for LNG carrier at anchor have been presented in Tab. 3 and Fig. 14.
Table 3. Statistical parameters

\begin{tabular}{lllll}
\hline \multicolumn{2}{l}{ Simulation Avarage } & $\begin{array}{l}\text { Standard } \\
\text { deviation }\end{array}$ & $\begin{array}{l}\text { Coefficient } \\
\text { of variation }\end{array}$ & $\begin{array}{l}\text { Standard } \\
\text { error }\end{array}$ \\
\hline 109 & 3,27415 & 0,375892 & $11,4806 \%$ & 0,00414447 \\
129 & 3,14816 & 0,503874 & $16,0054 \%$ & 0,00530718 \\
130 & 3,15613 & 0,452964 & $14,3519 \%$ & 0,00489842 \\
131 & 2,95505 & 0,592045 & $20,035 \%$ & 0,00618968 \\
132 & 2,89295 & 0,579977 & $20,0479 \%$ & 0,00574122 \\
133 & 3,10199 & 0,455714 & $14,691 \%$ & 0,0049907 \\
$134 a$ & 2,91225 & 0,677372 & $23,2594 \%$ & 0,00603451 \\
134 & 2,92489 & 0,66794 & $22,8364 \%$ & 0,00592026 \\
136 & 2,94684 & 0,717248 & $24,3396 \%$ & 0,00754747 \\
Sum & 3,0197 & 0,59489 & $19,7003 \%$ & 0,00200716 \\
\hline
\end{tabular}

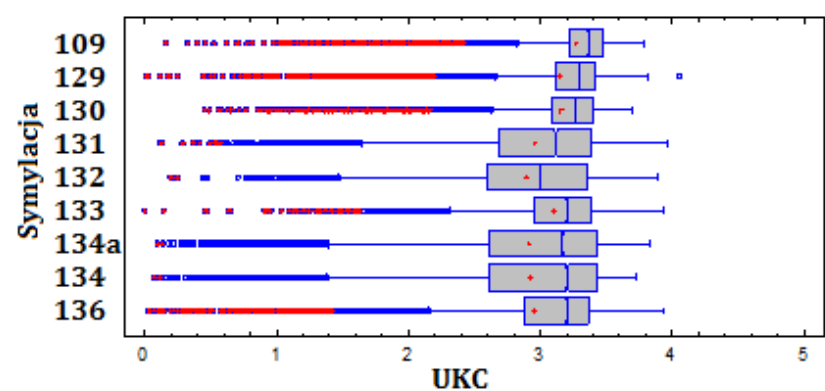

Figrue 14. Box plot for UKC for a model of LNG tanker at anchor

For the data obtained from the simulation, the Kruskal-Wallisai test was performed. The rank test for mean medians is shown in Table 4, Table 5 and Table 6. 
Table 4. Kruskal-Wallis test.

\begin{tabular}{lll}
\hline Simulation & Sample Size & Average Rank \\
\hline 109 & 8226 & 57605,1 \\
129 & 9014 & 49593,0 \\
130 & 8551 & 48131,0 \\
131 & 9149 & 39556,2 \\
132 & 10205 & 36338,5 \\
133 & 8338 & 44090,2 \\
$134 \mathrm{a}$ & 12600 & 41192,8 \\
$134 \mathrm{U}$ & 12729 & 41913,6 \\
136 & 9031 & 41288,4 \\
\hline
\end{tabular}

Test statistic $=4588,9$ P-Value $=0,0$

Method: 95,0 percent LSD

Table 5. Multiple rank test,

\begin{tabular}{lllc}
\hline Simulation & Count & Mean & Homogeneous Groups \\
\hline 132 & 10205 & 2,89295 & X \\
$134 \mathrm{a}$ & 12600 & 2,91225 & $\mathrm{X}$ \\
134 & 12729 & 2,92489 & $\mathrm{X}$ \\
136 & 9031 & 2,94684 & $\mathrm{X}$ \\
131 & 9149 & 2,95505 & $\mathrm{X}$ \\
133 & 8338 & 3,10199 & $\mathrm{X}$ \\
129 & 9014 & 3,14816 & $\mathrm{X}$ \\
130 & 8551 & 3,15613 & $\mathrm{X}$ \\
109 & 8226 & 3,27415 & $\mathrm{X}$ \\
\hline
\end{tabular}

Both the rank test for mean and the Kruskal-Wallis test for medians indicate a statistically significant differentiation of the samples, i.e. the influence of the wind direction and swell on under keel clearance.

Tab. 7 and Tab. 8. show classes of under keel clearance obtained from the simulation.

Probability of UKC not exceeding $1.2 \mathrm{~m}(10 \%$ reserve), $1.8 \mathrm{~m}$ (15\% reserve) and $2.4 \mathrm{~m}$ (20\% reserve) thresholds and not exceeding the $2.4 \mathrm{~m}$ threshold for a draft of $12 \mathrm{~m}$ and individual test variants are presented in Table 9.
Table 6. Test for simulation pairs

\begin{tabular}{llll}
\hline pairs & Sig. & difference & + - limits \\
\hline $109-129$ & $*$ & 0,12599 & 0,0173725 \\
$109-130$ & $*$ & 0,118016 & 0,0175955 \\
$109-131$ & $*$ & 0,319097 & 0,0173113 \\
$109-132$ & $*$ & 0,381193 & 0,0168819 \\
$109-133$ & $*$ & 0,172152 & 0,0177054 \\
$109-134 a$ & $*$ & 0,361896 & 0,01615 \\
$109-134$ & $*$ & 0,349255 & 0,0161176 \\
$109-136$ & $*$ & 0,327309 & 0,0173647 \\
$129-130$ & & $-0,0079734$ & 0,0171991 \\
$129-131$ & $*$ & 0,193107 & 0,0169082 \\
$129-132$ & $*$ & 0,255203 & 0,0164683 \\
$129-133$ & $*$ & 0,0461625 & 0,0173114 \\
$129-134 a$ & $*$ & 0,235907 & 0,0157171 \\
$129-134$ & $*$ & 0,223265 & 0,0156838 \\
$129-136$ & $*$ & 0,20132 & 0,0169629 \\
$130-131$ & $*$ & 0,20108 & 0,0171372 \\
$130-132$ & $*$ & 0,263176 & 0,0167033 \\
$130-133$ & $*$ & 0,0541359 & 0,0175352 \\
$130-134 a$ & $*$ & 0,24388 & 0,0159632 \\
$130-134$ & $*$ & 0,231239 & 0,0159305 \\
$130-136$ & $*$ & 0,209293 & 0,0171912 \\
$131-132$ & $*$ & 0,0620961 & 0,0164036 \\
$131-133$ & $*$ & $-0,146944$ & 0,01725 \\
$131-134$ & $*$ & 0,0427997 & 0,0156493 \\
$131-134$ & $*$ & 0,0301584 & 0,0156159 \\
$131-136$ & & 0,0082126 & 0,0169001 \\
$132-133$ & $*$ & $-0,209041$ & 0,016819 \\
$132-134 a$ & $*$ & $-0,0192964$ & 0,015173 \\
$132-134$ & $*$ & $-0,0319377$ & 0,0151385 \\
$132-136$ & $*$ & $-0,0538835$ & 0,01646 \\
$133-134 a$ & $*$ & 0,189744 & 0,0160842 \\
$133-134$ & $*$ & 0,177103 & 0,0160517 \\
$133-136$ & $*$ & 0,155157 & 0,0173036 \\
$134 \mathrm{a}-134$ & & $-0,0126413$ & 0,0143177 \\
$134 \mathrm{a}-136$ & $*$ & $-0,0345871$ & 0,0157084 \\
$134-136$ & $*$ & $-0,0219458$ & 0,0156752 \\
\hline
\end{tabular}

${ }^{*}$ means a statistically significant difference

The analysis of the impact of wind speed on UKC variable is presented in Table 10 and in Fig. 15

Table 7. Classification into classes for UKC.

\begin{tabular}{|c|c|c|c|c|c|c|c|c|c|c|}
\hline $\begin{array}{l}\mathrm{T} \\
\text { Range } \\
{[\mathrm{m}]}\end{array}$ & $\begin{array}{l}109 \\
\text { Relative } \\
\text { frequent }\end{array}$ & $\begin{array}{l}\text { Cumulative } \\
\text { relative } \\
\text { frequent }\end{array}$ & $\begin{array}{l}129 \\
\text { Relative } \\
\text { frequent }\end{array}$ & $\begin{array}{l}\text { Cumulative } \\
\text { relative } \\
\text { frequent }\end{array}$ & $\begin{array}{l}130 \\
\text { Relative } \\
\text { frequent }\end{array}$ & $\begin{array}{l}\text { Cumulative } \\
\text { relative } \\
\text { frequent }\end{array}$ & $\begin{array}{l}131 \\
\text { Relative } \\
\text { frequent }\end{array}$ & $\begin{array}{l}\text { Cumulative } \\
\text { relative } \\
\text { frequent }\end{array}$ & $\begin{array}{l}132 \\
\text { Relative } \\
\text { frequent }\end{array}$ & $\begin{array}{l}\text { Cumulative } \\
\text { relative } \\
\text { frequent }\end{array}$ \\
\hline$(0 ; 0,6]$ & $0,38 \%$ & $0,38 \%$ & $0,62 \%$ & $0,62 \%$ & $0,51 \%$ & $0,51 \%$ & $0,70 \%$ & $0,70 \%$ & $0,24 \%$ & $0,24 \%$ \\
\hline$(0,6 ; 1,2]$ & $0,26 \%$ & $0,63 \%$ & $0,59 \%$ & $1,21 \%$ & $0,49 \%$ & $1,01 \%$ & $0,86 \%$ & $1,56 \%$ & $0,82 \%$ & $1,07 \%$ \\
\hline$(1,2 ; 1,8]$ & $0,90 \%$ & $1,53 \%$ & $2,25 \%$ & $3,46 \%$ & $1,34 \%$ & $2,35 \%$ & $3,08 \%$ & $4,65 \%$ & $4,51 \%$ & $5,58 \%$ \\
\hline$(1,8 ; 2,4]$ & $1,60 \%$ & $3,14 \%$ & $4,27 \%$ & $7,73 \%$ & $2,60 \%$ & $4,95 \%$ & $9,12 \%$ & $13,76 \%$ & $12,30 \%$ & $17,87 \%$ \\
\hline$(2,4 ; 3]$ & $4,25 \%$ & $7,39 \%$ & $9,29 \%$ & $17,02 \%$ & $13,25 \%$ & $18,20 \%$ & $27,82 \%$ & $41,58 \%$ & $32,37 \%$ & $50,24 \%$ \\
\hline$(3 ; 3,6]$ & $92,57 \%$ & $99,96 \%$ & $82,85 \%$ & $99,87 \%$ & $81,25 \%$ & $99,45 \%$ & $55,77 \%$ & $97,34 \%$ & $46,14 \%$ & $96,38 \%$ \\
\hline$\geqslant 3,6$ & $0,04 \%$ & $100,00 \%$ & $0,13 \%$ & $100,00 \%$ & $0,55 \%$ & $100,00 \%$ & $2,66 \%$ & $100,00 \%$ & $3,62 \%$ & $100,00 \%$ \\
\hline
\end{tabular}

Table 8. Classification into classes for UKC.

\begin{tabular}{|c|c|c|c|c|c|c|c|c|}
\hline $\begin{array}{l}\mathrm{T} \\
\text { Range } \\
{[\mathrm{m}]}\end{array}$ & $\begin{array}{l}133 \\
\text { Relative } \\
\text { frequent }\end{array}$ & $\begin{array}{l}\text { Cumulative } \\
\text { relative } \\
\text { frequent }\end{array}$ & $\begin{array}{l}134 \mathrm{a} \\
\text { Relative } \\
\text { frequent }\end{array}$ & $\begin{array}{l}\text { Cumulative } \\
\text { relative } \\
\text { frequent }\end{array}$ & $\begin{array}{l}134 \\
\text { Relative } \\
\text { frequent }\end{array}$ & $\begin{array}{l}\text { Cumulative } \\
\text { relative } \\
\text { frequent }\end{array}$ & $\begin{array}{l}136 \\
\text { Relative } \\
\text { frequent }\end{array}$ & $\begin{array}{l}\text { Cumulative } \\
\text { relative } \\
\text { frequent }\end{array}$ \\
\hline$(0 ; 0,6]$ & $0,62 \%$ & $0,62 \%$ & $0,52 \%$ & $0,52 \%$ & $0,43 \%$ & $0,43 \%$ & $1,72 \%$ & $1,72 \%$ \\
\hline$(0,6 ; 1,2]$ & $0,19 \%$ & $0,82 \%$ & $2,42 \%$ & $2,94 \%$ & $2,26 \%$ & $2,69 \%$ & $2,10 \%$ & $3,82 \%$ \\
\hline$(1,2 ; 1,8]$ & $0,65 \%$ & $1,46 \%$ & $6,37 \%$ & $9,31 \%$ & $6,06 \%$ & $8,75 \%$ & $4,55 \%$ & $8,37 \%$ \\
\hline$(1,8 ; 2,4]$ & $3,63 \%$ & $5,10 \%$ & $10,87 \%$ & $20,17 \%$ & $11,53 \%$ & $20,28 \%$ & $6,44 \%$ & $14,82 \%$ \\
\hline$(2,4 ; 3]$ & $23,81 \%$ & $28,90 \%$ & $16,28 \%$ & $36,45 \%$ & $15,40 \%$ & $35,68 \%$ & $15,48 \%$ & $30,30 \%$ \\
\hline$(3 ; 3,6]$ & $69,61 \%$ & $98,51 \%$ & $63,29 \%$ & $99,75 \%$ & $64,21 \%$ & $99,89 \%$ & $68,84 \%$ & $99,14 \%$ \\
\hline$\geqslant 3,6$ & $1,49 \%$ & $100,00 \%$ & $0,25 \%$ & $100,00 \%$ & $0,11 \%$ & $100,00 \%$ & $0,86 \%$ & $100,00 \%$ \\
\hline
\end{tabular}


Table 9. Probability of occurrence of under keel clearance (UKC)

\begin{tabular}{llllllllll}
\hline Probability & 109 & 129 & 130 & 131 & 132 & 133 & $134 a$ & 134 & 136 \\
\hline UKC $\leqslant 1,2$ & $0,63 \%$ & $1,21 \%$ & $1,01 \%$ & $1,56 \%$ & $1,07 \%$ & $0,82 \%$ & $2,94 \%$ & $2,69 \%$ & $3,82 \%$ \\
UKC $\leqslant 1,8$ & $1,53 \%$ & $3,46 \%$ & $2,35 \%$ & $4,65 \%$ & $5,58 \%$ & $1,46 \%$ & $9,31 \%$ & $8,75 \%$ & $8,37 \%$ \\
UKC $\leqslant 2,4$ & $3,14 \%$ & $7,73 \%$ & $4,95 \%$ & $13,76 \%$ & $17,87 \%$ & $5,10 \%$ & $20,17 \%$ & $20,28 \%$ & $14,82 \%$ \\
UKC $>2,4$ & $96,86 \%$ & $92,27 \%$ & $95,05 \%$ & $86,24 \%$ & $82,13 \%$ & $94,90 \%$ & $79,83 \%$ & $79,72 \%$ & $85,18 \%$ \\
\hline
\end{tabular}

Table 10. Statistical Parameters

\begin{tabular}{llllll}
\hline Wind speed & UKC avarage & Standard deviation & Coefficient of variation & Qantile quarter & Quantile six \\
\hline up to $10 \mathrm{~m} / \mathrm{s}$ & 3,28688 & 0,417243 & $12,6942 \%$ & 3,30235 & 3,14154 \\
up to $12 \mathrm{~m} / \mathrm{s}$ & 3,28151 & 0,421774 & $12,853 \%$ & 3,29012 & 3,12717 \\
up to $14 \mathrm{~m} / \mathrm{s}$ & 3,29642 & 0,383915 & $11,6464 \%$ & 3,30065 & 3,15747 \\
up to $16 \mathrm{~m} / \mathrm{s}$ & 3,2585 & 0,312357 & $9,58591 \%$ & 3,16783 & 3,0837 \\
up to $18 \mathrm{~m} / \mathrm{s}$ & 3,06272 & 0,579803 & $18,931 \%$ & 2,99711 & 2,72243 \\
up to $20 \mathrm{~m} / \mathrm{s}$ & 3,06384 & 0,579493 & $18,9139 \%$ & 2,9987 & 2,72492 \\
up to $20 \mathrm{~m} / \mathrm{s}$ & 2,80615 & 0,73121 & $26,0574 \%$ & 2,5247 & 2,16831 \\
$10-12 \mathrm{~m} / \mathrm{s}$ & 3,02875 & 0,540676 & $17,8514 \%$ & 2,89459 & 2,56924 \\
$12-14 \mathrm{~m} / \mathrm{s}$ & 3,33355 & 0,263622 & $7,90815 \%$ & 3,31599 & 3,21929 \\
$14-16 \mathrm{~m} / \mathrm{s}$ & 3,22122 & 0,213972 & $6,64257 \%$ & 3,12269 & 3,06042 \\
$16-18 \mathrm{~m} / \mathrm{s}$ & 2,61657 & 0,770409 & $29,4435 \%$ & 2,14196 & 1,84353 \\
$18-20 \mathrm{~m} / \mathrm{s}$ & 3,24475 & 0,495649 & $15,2754 \%$ & 3,2171 & 3,10972 \\
\hline
\end{tabular}

Table 11. Probabilities for UKC variable for different wind speed.

\begin{tabular}{|c|c|c|c|c|c|c|c|c|c|c|c|c|}
\hline \multirow{2}{*}{$\begin{array}{l}\text { Vw } \\
\text { Range } \\
\text { UKC [m] }\end{array}$} & \multicolumn{2}{|c|}{$\begin{array}{l}\text { up to } 10 \mathrm{~m} / \mathrm{s} \\
\text { UKC_10 }\end{array}$} & \multicolumn{2}{|c|}{$\begin{array}{l}\text { up to } 12 \mathrm{~m} / \mathrm{s} \\
\text { UKC_12 }\end{array}$} & \multicolumn{2}{|c|}{$\begin{array}{l}\text { up to } 14 \mathrm{~m} / \mathrm{s} \\
\text { UKC_14 }\end{array}$} & \multicolumn{2}{|c|}{$\begin{array}{l}\text { up to } 16 \mathrm{~m} / \mathrm{s} \\
\text { UKC_16 }\end{array}$} & \multicolumn{2}{|c|}{$\begin{array}{l}\text { up to } 18 \mathrm{~m} / \mathrm{s} \\
\text { UKC_18 }\end{array}$} & \multicolumn{2}{|c|}{$\begin{array}{l}\text { up to } 20 \mathrm{~m} / \mathrm{s} \\
\text { UKC_20 }\end{array}$} \\
\hline & $\begin{array}{l}\text { Relative } \\
\text { frequent }\end{array}$ & $\begin{array}{l}\text { Cumulative } \\
\text { relative } \\
\text { frequent }\end{array}$ & $\begin{array}{l}\text { Relative } \\
\text { frequent }\end{array}$ & $\begin{array}{l}\text { Cumulative } \\
\text { relative } \\
\text { frequent }\end{array}$ & $\begin{array}{l}\text { Relative } \\
\text { frequent }\end{array}$ & $\begin{array}{l}\text { Cumulative } \\
\text { relative } \\
\text { frequent }\end{array}$ & $\begin{array}{l}\text { Relative } \\
\text { frequent }\end{array}$ & $\begin{array}{l}\text { Cumulative } \\
\text { relative } \\
\text { frequent }\end{array}$ & $\begin{array}{l}\text { Relative } \\
\text { frequent }\end{array}$ & $\begin{array}{l}\text { Cumulative } \\
\text { relative } \\
\text { frequent }\end{array}$ & $\begin{array}{l}\text { RelativeC } \\
\text { frequent }\end{array}$ & $\begin{array}{l}\text { umulative } \\
\text { relative } \\
\text { frequent }\end{array}$ \\
\hline$[0 ; 0,1]$ & $0,00 \%$ & $0,00 \%$ & $0,00 \%$ & $0,00 \%$ & $0,01 \%$ & $0,01 \%$ & $0,01 \%$ & $0,01 \%$ & $0,31 \%$ & $0,31 \%$ & $0,31 \%$ & $0,31 \%$ \\
\hline$[0,1 ; 0,3]$ & $0,01 \%$ & $0,01 \%$ & $0,01 \%$ & $0,01 \%$ & $0,01 \%$ & $0,02 \%$ & $0,00 \%$ & $0,01 \%$ & $0,05 \%$ & $0,36 \%$ & $0,05 \%$ & $0,36 \%$ \\
\hline$[0,3 ; 0,5]$ & $0,02 \%$ & $0,03 \%$ & $0,03 \%$ & $0,04 \%$ & $0,02 \%$ & $0,04 \%$ & $0,01 \%$ & $0,02 \%$ & $0,12 \%$ & $0,48 \%$ & $0,13 \%$ & $0,49 \%$ \\
\hline$[0,5 ; 0,7]$ & $0,06 \%$ & $0,10 \%$ & $0,06 \%$ & $0,10 \%$ & $0,05 \%$ & $0,09 \%$ & $0,02 \%$ & $0,05 \%$ & $0,16 \%$ & $0,64 \%$ & $0,16 \%$ & $0,65 \%$ \\
\hline$[0,7 ; 0,9]$ & $0,16 \%$ & $0,26 \%$ & $0,16 \%$ & $0,26 \%$ & $0,13 \%$ & $0,21 \%$ & $0,07 \%$ & $0,12 \%$ & $0,35 \%$ & $1,00 \%$ & $0,35 \%$ & $1,00 \%$ \\
\hline$[0,9 ; 1,1]$ & $0,23 \%$ & $0,49 \%$ & $0,25 \%$ & $0,51 \%$ & $0,19 \%$ & $0,40 \%$ & $0,10 \%$ & $0,21 \%$ & $0,54 \%$ & $1,53 \%$ & $0,53 \%$ & $1,53 \%$ \\
\hline$[1,1 ; 1,3]$ & $0,36 \%$ & $0,85 \%$ & $0,35 \%$ & $0,86 \%$ & $0,27 \%$ & $0,67 \%$ & $0,15 \%$ & $0,36 \%$ & $0,76 \%$ & $2,29 \%$ & $0,76 \%$ & $2,29 \%$ \\
\hline$[1,3 ; 1,5]$ & $0,43 \%$ & $1,28 \%$ & $0,44 \%$ & $1,30 \%$ & $0,32 \%$ & $0,99 \%$ & $0,17 \%$ & $0,53 \%$ & $1,01 \%$ & $3,30 \%$ & $1,00 \%$ & $3,29 \%$ \\
\hline$[1,5 ; 1,7]$ & $0,55 \%$ & $1,83 \%$ & $0,58 \%$ & $1,88 \%$ & $0,43 \%$ & $1,41 \%$ & $0,22 \%$ & $0,75 \%$ & $1,27 \%$ & $4,58 \%$ & $1,27 \%$ & $4,56 \%$ \\
\hline$[1,7 ; 1,9]$ & $0,71 \%$ & $2,55 \%$ & $0,74 \%$ & $2,61 \%$ & $0,57 \%$ & $1,98 \%$ & $0,32 \%$ & $1,07 \%$ & $1,70 \%$ & $6,27 \%$ & $1,69 \%$ & $6,26 \%$ \\
\hline$[1,9 ; 2,1]$ & $0,78 \%$ & $3,33 \%$ & $0,82 \%$ & $3,43 \%$ & $0,65 \%$ & $2,63 \%$ & $0,39 \%$ & $1,45 \%$ & $1,98 \%$ & $8,26 \%$ & $1,98 \%$ & $8,23 \%$ \\
\hline$[2,1 ; 2,3]$ & $0,83 \%$ & $4,16 \%$ & $0,88 \%$ & $4,31 \%$ & $0,72 \%$ & $3,35 \%$ & $0,47 \%$ & $1,92 \%$ & $2,19 \%$ & $10,45 \%$ & $2,18 \%$ & $10,41 \%$ \\
\hline$[2,3 ; 2,5]$ & $1,66 \%$ & $5,82 \%$ & $1,70 \%$ & $6,01 \%$ & $1,52 \%$ & $4,88 \%$ & $0,97 \%$ & $2,89 \%$ & $2,66 \%$ & $13,11 \%$ & $2,65 \%$ & $13,07 \%$ \\
\hline$[2,5 ; 2,7]$ & $2,32 \%$ & $8,14 \%$ & $2,39 \%$ & $8,40 \%$ & $2,01 \%$ & $6,89 \%$ & $1,57 \%$ & $4,46 \%$ & $3,10 \%$ & $16,21 \%$ & $3,10 \%$ & $16,16 \%$ \\
\hline$[2,7 ; 2,9]$ & $2,75 \%$ & $10,89 \%$ & $2,79 \%$ & $11,19 \%$ & $2,91 \%$ & $9,80 \%$ & $3,36 \%$ & $7,82 \%$ & $4,82 \%$ & $21,03 \%$ & $4,81 \%$ & $20,97 \%$ \\
\hline$[2,9 ; 3,1]$ & $4,28 \%$ & $15,17 \%$ & $4,48 \%$ & $15,67 \%$ & $4,54 \%$ & $14,34 \%$ & $10,13 \%$ & $17,95 \%$ & $10,79 \%$ & $31,83 \%$ & $10,76 \%$ & $31,73 \%$ \\
\hline$[3,1 ; 3,3]$ & $9,72 \%$ & $24,88 \%$ & $9,98 \%$ & $25,65 \%$ & $10,62 \%$ & $24,96 \%$ & $25,79 \%$ & $43,74 \%$ & $24,17 \%$ & $56,00 \%$ & $24,11 \%$ & $55,84 \%$ \\
\hline$(3,3 ; 3,5]$ & $70,78 \%$ & $95,66 \%$ & $70,04 \%$ & $95,69 \%$ & $70,70 \%$ & $95,66 \%$ & $52,10 \%$ & $95,84 \%$ & $40,49 \%$ & $96,48 \%$ & $40,65 \%$ & $96,49 \%$ \\
\hline$(3,5 ; 3,7]$ & $4,33 \%$ & $99,99 \%$ & $4,30 \%$ & $99,99 \%$ & $4,30 \%$ & $99,96 \%$ & $4,08 \%$ & $99,92 \%$ & $3,43 \%$ & $99,92 \%$ & $3,43 \%$ & $99,92 \%$ \\
\hline$(3,7 ; 3,9]$ & $0,01 \%$ & $100,00 \%$ & $0,01 \%$ & $100,00 \%$ & $0,04 \%$ & $100,00 \%$ & $0,08 \%$ & $100,00 \%$ & $0,08 \%$ & $100,00 \%$ & $0,08 \%$ & $100,00 \%$ \\
\hline
\end{tabular}

Table 12. Probabilities for UKC variable for different wind speed.

\begin{tabular}{|c|c|c|c|c|c|c|c|c|c|c|c|c|}
\hline \multirow{2}{*}{$\begin{array}{l}\text { Vw } \\
\text { Range } \\
\text { UKC [m] }\end{array}$} & \multicolumn{2}{|c|}{$\begin{array}{l}\text { from } 20 \mathrm{~m} / \mathrm{s} \\
\text { UKC_from } 20\end{array}$} & \multicolumn{2}{|c|}{$\begin{array}{l}10 \mathrm{~m} / \mathrm{s}-12 \mathrm{~m} / \mathrm{s} \\
\mathrm{UKC} 10 \_12\end{array}$} & \multicolumn{2}{|c|}{$\begin{array}{l}12 \mathrm{~m} / \mathrm{s}-14 \mathrm{~m} / \mathrm{s} \\
\mathrm{UKC} 12 \_14\end{array}$} & \multicolumn{2}{|c|}{$\begin{array}{l}14 \mathrm{~m} / \mathrm{s}-16 \mathrm{~m} / \mathrm{s} \\
\mathrm{UKC} 14 \_16\end{array}$} & \multicolumn{2}{|c|}{$\begin{array}{l}16 \mathrm{~m} / \mathrm{s}-18 \mathrm{~m} / \mathrm{s} \\
\mathrm{UKC} 16 \_18\end{array}$} & \multicolumn{2}{|c|}{$\begin{array}{l}18 \mathrm{~m} / \mathrm{s}-20 \mathrm{~m} / \mathrm{s} \\
\text { UKC18_20 } \\
\text { RelativeCumulative }\end{array}$} \\
\hline & $\begin{array}{l}\text { Relative } \\
\text { frequent }\end{array}$ & $\begin{array}{l}\text { Cumulative } \\
\text { relative } \\
\text { frequent }\end{array}$ & $\begin{array}{l}\text { Relative } \\
\text { frequent }\end{array}$ & $\begin{array}{l}\text { Cumulative } \\
\text { relative } \\
\text { frequent }\end{array}$ & $\begin{array}{l}\text { Relative } \\
\text { frequent }\end{array}$ & $\begin{array}{l}\text { Cumulative } \\
\text { relative } \\
\text { frequent }\end{array}$ & $\begin{array}{l}\text { Relative } \\
\text { frequent }\end{array}$ & $\begin{array}{l}\text { Cumulative } \\
\text { relative } \\
\text { frequent }\end{array}$ & $\begin{array}{l}\text { Relative } \\
\text { frequent }\end{array}$ & $\begin{array}{l}\text { Cumulative } \\
\text { relative } \\
\text { frequent }\end{array}$ & $\begin{array}{l}\text { RelativeC } \\
\text { frequent }\end{array}$ & $\begin{array}{l}\text { umulative } \\
\text { relative } \\
\text { frequent }\end{array}$ \\
\hline$[0 ; 0,1]$ & $1,44 \%$ & $1,44 \%$ & $0,00 \%$ & $0,00 \%$ & $0,03 \%$ & $0,03 \%$ & $0,01 \%$ & $0,01 \%$ & $0,99 \%$ & $0,99 \%$ & $0,53 \%$ & $0,53 \%$ \\
\hline$(0,1 ; 0,3]$ & $0,07 \%$ & $1,52 \%$ & $0,00 \%$ & $0,00 \%$ & $0,00 \%$ & $0,03 \%$ & $0,00 \%$ & $0,01 \%$ & $0,16 \%$ & $1,15 \%$ & $0,00 \%$ & $0,53 \%$ \\
\hline$(0,3 ; 0,5]$ & $0,17 \%$ & $1,69 \%$ & $0,32 \%$ & $0,32 \%$ & $0,00 \%$ & $0,03 \%$ & $0,00 \%$ & $0,01 \%$ & $0,38 \%$ & $1,53 \%$ & $0,53 \%$ & $1,06 \%$ \\
\hline$(0,5 ; 0,7]$ & $0,30 \%$ & $1,99 \%$ & $0,00 \%$ & $0,32 \%$ & $0,02 \%$ & $0,05 \%$ & $0,00 \%$ & $0,01 \%$ & $0,48 \%$ & $2,01 \%$ & $0,00 \%$ & $1,06 \%$ \\
\hline$(0,7 ; 0,9]$ & $0,65 \%$ & $2,64 \%$ & $0,00 \%$ & $0,32 \%$ & $0,05 \%$ & $0,10 \%$ & $0,01 \%$ & $0,02 \%$ & $1,00 \%$ & $3,00 \%$ & $0,00 \%$ & $1,06 \%$ \\
\hline$(0,9 ; 1,1]$ & $0,67 \%$ & $3,31 \%$ & $0,96 \%$ & $1,28 \%$ & $0,03 \%$ & $0,13 \%$ & $0,01 \%$ & $0,03 \%$ & $1,54 \%$ & $4,55 \%$ & $0,00 \%$ & $1,06 \%$ \\
\hline$(1,1 ; 1,3]$ & $1,19 \%$ & $4,50 \%$ & $0,00 \%$ & $1,28 \%$ & $0,07 \%$ & $0,20 \%$ & $0,03 \%$ & $0,06 \%$ & $2,16 \%$ & $6,70 \%$ & $0,00 \%$ & $1,06 \%$ \\
\hline$(1,3 ; 1,5]$ & $1,49 \%$ & $5,99 \%$ & $0,64 \%$ & $1,92 \%$ & $0,02 \%$ & $0,22 \%$ & $0,02 \%$ & $0,07 \%$ & $2,92 \%$ & $9,63 \%$ & $0,53 \%$ & $1,58 \%$ \\
\hline$(1,5 ; 1,7]$ & $1,89 \%$ & $7,88 \%$ & $1,92 \%$ & $3,83 \%$ & $0,05 \%$ & $0,27 \%$ & $0,02 \%$ & $0,10 \%$ & $3,66 \%$ & $13,29 \%$ & $1,06 \%$ & $2,64 \%$ \\
\hline$(1,7 ; 1,9]$ & $3,31 \%$ & $11,19 \%$ & $1,92 \%$ & $5,75 \%$ & $0,15 \%$ & $0,41 \%$ & $0,07 \%$ & $0,16 \%$ & $4,85 \%$ & $18,14 \%$ & $0,79 \%$ & $3,43 \%$ \\
\hline$(1,9 ; 2,1]$ & $3,85 \%$ & $15,05 \%$ & $2,56 \%$ & $8,31 \%$ & $0,22 \%$ & $0,63 \%$ & $0,14 \%$ & $0,30 \%$ & $5,62 \%$ & $23,76 \%$ & $0,53 \%$ & $3,96 \%$ \\
\hline$(2,1 ; 2,3]$ & $3,90 \%$ & $18,95 \%$ & $3,19 \%$ & $11,50 \%$ & $0,33 \%$ & $0,96 \%$ & $0,22 \%$ & $0,52 \%$ & $6,11 \%$ & $29,87 \%$ & $1,06 \%$ & $5,01 \%$ \\
\hline$(2,3 ; 2,5]$ & $5,32 \%$ & $24,27 \%$ & $3,51 \%$ & $15,02 \%$ & $1,09 \%$ & $2,06 \%$ & $0,42 \%$ & $0,94 \%$ & $6,53 \%$ & $36,40 \%$ & $1,06 \%$ & $6,07 \%$ \\
\hline$(2,5 ; 2,7]$ & $5,22 \%$ & $29,50 \%$ & $5,43 \%$ & $20,45 \%$ & $1,08 \%$ & $3,13 \%$ & $1,13 \%$ & $2,07 \%$ & $6,60 \%$ & $43,00 \%$ & $2,11 \%$ & $8,18 \%$ \\
\hline$(2,7 ; 2,9]$ & $7,63 \%$ & $37,13 \%$ & $5,11 \%$ & $25,56 \%$ & $3,22 \%$ & $6,35 \%$ & $3,79 \%$ & $5,86 \%$ & $8,15 \%$ & $51,15 \%$ & $2,64 \%$ & $10,82 \%$ \\
\hline$(2,9 ; 3,1]$ & $15,24 \%$ & $52,38 \%$ & $13,74 \%$ & $39,30 \%$ & $4,69 \%$ & $11,04 \%$ & $15,64 \%$ & $21,50 \%$ & $12,30 \%$ & $63,44 \%$ & $5,28 \%$ & $16,09 \%$ \\
\hline
\end{tabular}




\begin{tabular}{|c|c|c|c|c|c|c|c|c|c|c|c|c|}
\hline$(3,1 ; 3,3]$ & $25,02 \%$ & $77,39 \% 2$ & $2,36 \%$ & $61,66 \%$ & $12,21 \%$ & $23,25 \%$ & $40,70 \%$ & $62,19 \%$ & $20,50 \%$ & $83,94 \%$ & $13,46 \%$ & $29,55 \%$ \\
\hline$(3,3 ; 3,5]$ & $20,69 \%$ & $98,09 \%$ & $35,46 \%$ & $97,12 \%$ & $72,34 \%$ & $95,59 \%$ & $33,82 \%$ & $96,01 \%$ & $14,01 \%$ & $97,96 \%$ & $67,28 \%$ & $96,83 \%$ \\
\hline$(3,5 ; 3,7]$ & $1,91 \%$ & $100,00 \%$ & $2,88 \%$ & $100,00 \%$ & $4,29 \%$ & $99,88 \%$ & $3,86 \%$ & $99,88 \%$ & $1,96 \%$ & $99,92 \%$ & $2,90 \%$ & $99,74 \%$ \\
\hline$(3,7 ; 3,9]$ & $0,00 \%$ & & $0,00 \%$ & & $0,12 \%$ & $100,00 \%$ & $0,12 \%$ & $100,00 \%$ & $0,08 \%$ & $99,99 \%$ & $0,00 \%$ & $99,74 \%$ \\
\hline$(3,9 ; 4,1]$ & & & & & & & & & $0,01 \%$ & $100,00 \%$ & $0,26 \%$ & $100,00 \%$ \\
\hline
\end{tabular}

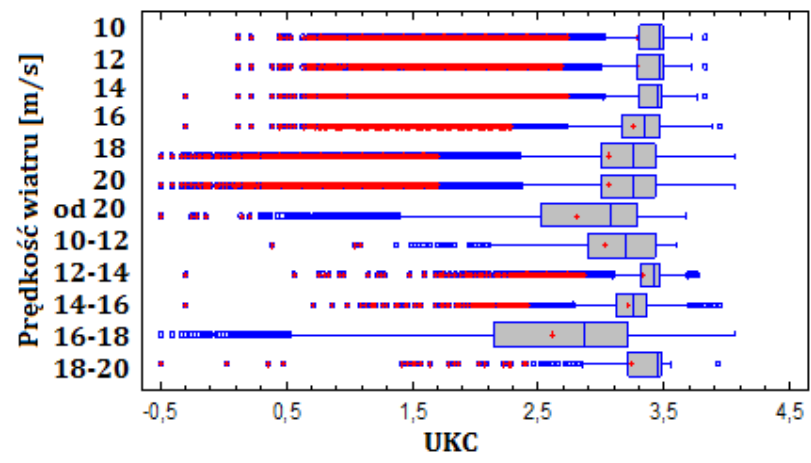

Figure 15. Box plot for UKC for a model of LNG vessel at anchor with different wind speed limits.

The simulation conclusions are included in Tab. 11 and Table 12, which contain the event probabilities that UKC variable [m] takes values from a given range for different wind speed ranges.

\section{CONCLUSIONS}

Designating safe anchorages for LNG carriers is one of the main tasks for safe operation of a terminal handling liquid fuels, especially LNG.

Important issue is the influence of hydrometeorological conditions in determining the anchorage areas for LNG carriers.

The aim of the simulations was to indicate the conditions that should be taken into account when determining the anchorage, so that under keel clearance was proper during the entire period of the ship's stay at anchor in various weather conditions.

The simulations and analysis (Tab. 2.1 and Tab. 2.2) have shown that the probability of a change in under keel clearance to the limit values ranging from $0.0 \mathrm{~m}$ to $0.1 \mathrm{~m}$ may occur with a probability frequency of $0.01 \%$ at wind speed $16 \mathrm{~m} / \mathrm{s}$ (31kts).

The increase in wind speed above $16 \mathrm{~m} / \mathrm{s}$ (31 kts) results in the increase in frequency of UKC occurrence by $0.0 \mathrm{~m}$ to $0.1 \mathrm{~m}$ with a probability of
$0.99 \%$. On the basis of the above values, it can be assumed that the UKC for No. 3 anchorage area, has safe values (for this type of LNG carrier) up to wind speed of $16 \mathrm{~m} / \mathrm{s}$ (31 kts). The ship model was at anchor/brought up all the time of simulation. Dragging of the anchor only occurred in the event of disturbances caused by squall. Simulation tests and their analysis have indicated that a vessel can lie at anchor at No. 3 anchorage safely with wind speed up to $16 \mathrm{~m} / \mathrm{s}(31 \mathrm{kts})$. With expected wind speed above $16 \mathrm{~m} / \mathrm{s}$ (31 knots), recommendation for the vessel is to heave up anchor and move for deeper open water.

The used methodology of simulation tests can be used to determine the conditions of safe anchoring for this type and size of ships taking into account their under keel clearance in various weather conditions.

\section{REFERENCES}

1. Załącznik graficzny $\mathrm{nr} 1$ do wniosku o wydanie pozwolenia na wznoszenie konstrukcji w polskich obszarach morskich. / Graphic appendix No. 1 to the application for a permit to erect structures in Polish sea areas

2. Pozwolenie Ministra Infrastruktury $\mathrm{nr} 48 / 08 \mathrm{z}$ dnia 19 czerwca 2011 r./ Permit of the Minister of Infrastructure No. 48/08 of June 19, 2011.

3. Pismo Dyrektora Urzędu Morskiego Znak: TI220/9/1383/2011 z dnia 06.06.2011 r./ Letter of the Director of the Maritime Office Ref: TI-220/9/1383/2011 from 06.06.2011.

4. Wyniki badań falowania $\mathrm{w}$ porcie zewnętrznym $\mathrm{w}$ Świnoujściu (optymalny wariant lokalizacji) wykonane przez BMT Cordahsp.z o.o. w Gdańsku / The results of wave tests in the external port in Świnoujście (optimal location variant) made by BMT Cordahsp. in Gdansk

5. Proj. Nr OW-22/12-2/2005 „WUPROHYD” Gdynia

6. G. Rutkowski, „Ocena głębokości północnego toru podejściowego do portu Swinoujście od pozycji gazo portu NordStream do terminalu LNG w aspekcie obsługi jednostek o maksymalnych gabarytach". 